UDC 621.316 .13

\title{
ANALYSIS OF THE STRUCTURES OF ALGEBRAIC DYNAMICAL SYSTEMS BASED ON A COMPUTER SOLUTION OF THE GENERALIZED ARTIN HYPOTHESIS
}

\author{
G. Vostrov, R. Opiata \\ Odessa national polytechnic university
}

\begin{abstract}
The article considers the generalized Artin's hypothesis. The analysis of algebraic dynamical systems on the set of prime numbers is given. The properties of dynamic algebraic systems are studied. Based on computer modeling, a solution of Artin's generalized hypothesis was constructed. A classification of prime numbers for any natural number $a \geq 1$ is constructed. The properties of classes of prime numbers are investigated. A method of structural analysis of algebraic dynamical systems with close values of generalized Artin constants was developed. It is established that for any $a \geq 1$ each class has a probability measure, and the sum of the measures of the classes tends to unity.
\end{abstract}

Key word: Generalized Artin's hypothesis. Algebraic dynamical system. Computer solution of the generalized Artin's hypothesis. Classification of prime numbers on the basis of a .

\section{Introduction}

It can be argued that for almost a hundred years Artin's hypothesis has been the object of research for groups of mathematicians, research mathematical centers, universities $[1,2,3]$ as well as individual mathematicians [4]. In recent years, fundamental reviews of all scientific publications have appeared to one degree or another aimed at the synthesis and particular solution of this problem. A review article by Moree [4] should be highlighted with a rather indepth analysis of various methods for solving the Artin problem. In the review of the author for the case $a=2$, it gives an estimate of $A(1)=0,3739 \ldots$ which is Artin's constant $c(2)$ i.e. $c(2)=A(1)$. This estimate of the Artin constant for $a=2$ is derived from the expression:

$$
A(1)=\prod_{p \geq 2}\left(1-\frac{1}{p(p-1)}\right)
$$

where $P$ is the set of all prime numbers. In Moree work does not provide analytical proof of this relationship.

In Carella work [5], an attempt was made to generalize Artin's hypothesis to a set of composite numbers that have a generalized primitive root. At the same time, the author, along with the Euler function $\varphi(p)$, uses its analogue Carmichael $\lambda(m)$ function which, according to the author's statement, satisfies the relation:

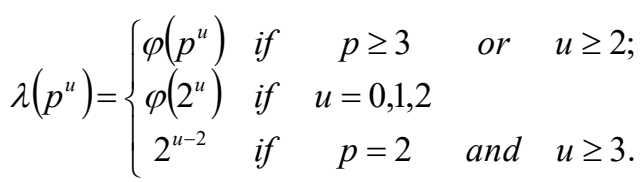

At the same time, the author stipulates that in a few other cases other relations between functions take place. However, in all cases $a^{\lambda(n)} \equiv 1(\bmod n)$.

The generalization of Carella [5] for Artin's hypothesis is that, in addition to the set of all primes, the case of the set $N_{2}$ is considered, which include composite numbers for which $a=2$ the primitive root extends to composite numbers, according to the author, has the form:

$$
N_{2}=\left\{3,5,3^{2}, 11,3 \cdot 5,19,5^{2}, 3^{3}, 29,3 \cdot 11,37,45, \ldots\right\}
$$

Instead of $p$, it was proposed to consider $P_{2} \subset N_{2}$ with $p_{2} \subseteq P_{2}$ i.e. the set of all primes for which $a=2$ is the primitive root of the proper subset $P_{2}$ of the set of all primes $P$. The concept of a primitive root for compound numbers is based on the fulfillment of the equality $2^{\lambda(n)} \equiv 1(\bmod n)$. Such a generalization of the concept of primitive root to the case of compound numbers $n$ can be considered correct. On the basis of this definition, the asymptotic formula $N_{2}(x)=\left|\left\{n \leq x \mid \operatorname{ord}_{n}(2)=\lambda(n)\right\}\right| \quad$ at $x \rightarrow \infty \quad$ is introduced in the work.

In this paper, an attempt is made to prove that the asymptotic relation holds:

$$
N_{2}(x)=\left(\frac{e^{v_{2}-v \alpha_{2}}}{\Gamma\left(\alpha_{2}\right)}+O(1)\right) \frac{x}{(\log x)^{1-\alpha_{2}}} \prod_{p \in W}\left(1-\frac{1}{p^{2}}\right)
$$

where $W$ is defined by the relation, $v_{2}$ is the Euler constant calculated for the set of primes $P_{2}$.

$$
W=\left\{p \in P \mid 2^{p-1}-1 \equiv O(\bmod p) \& 2^{p-1}-1 \equiv O\left(\bmod p^{2}\right)\right\}
$$

(C) G. Vostrov, R. Opiata, 2019 
The author generalizes this relation to the case of any $a>2$ fair to assume:

$$
N_{a}(x)=\left(\frac{e^{v_{u}-v \alpha_{u}}}{\Gamma\left(\alpha_{u}\right)}+O(1)\right) \frac{x}{(\log x)^{1-\alpha_{u}}} \cdot \prod_{p \in W}\left(1-\frac{1}{p^{2}}\right)
$$

where $v_{u}$ and $\alpha_{u}$ are Euler and Artin constants for $a=u$, respectively. It is assumed that $v$ is Euler's constant, and its generalization to the case of a set of numbers consisting of such natural numbers for which $a$ is a generalized primitive root, i.e. there are equality:

$$
\begin{gathered}
\sum_{p \leq x} \frac{1}{p}=\ln \ln x+v+O\left(\frac{1}{\log x}\right) \\
\sum_{m \leq x \& n \in N_{a}(x)} \frac{1}{n}=\ln \ln x \cdot \alpha_{a}+v_{a}+O\left(\frac{1}{\log x}\right) \alpha_{a}
\end{gathered}
$$

where $N_{a}(x)$ is the set of natural numbers for which $a$ is a primitive root i.e. $a^{\lambda(n)} \equiv(\bmod n), \alpha_{a}$ is the constant $c(a)$ of Artin, and $v_{u}$ is the Euler constant which can be calculated asymptotically:

$$
v_{u}=\sum_{p \in P_{u}, p \leq 1000} \frac{1000}{p-1}-\alpha_{u} \log x \text { и } x \leq 1000 .
$$

In the following, instead of the $u$ symbol used by Corell, we will denote the symbol $a$.

The above relations for the case of $a>2$ are not strictly proved. This is especially noticeable for the expression $v_{a}$, which includes $\alpha_{a}$, which is unknown. Equality (2) is known as the Mertens formula [6], the validity of relation (3) requires rigorous proof. Therefore, relations (1.1) and (4) must also be rigorously proved. The case of $a=2$ is consistent with the review by Moree [4]; moreover, such estimates of $c(2)=\alpha_{2}$ are given in [5].

It should be noted that the Artin Mertens $\beta_{a}$ and Artin-Euler $v_{a}$ constants are introduced in Carella [5], which have equivalent definitions:

$$
\begin{gathered}
\beta_{a}=\lim _{x \rightarrow \infty}\left(\sum_{p \leq x, p \in P_{a}} \frac{1}{p}-\alpha_{a} \log \log x\right) \\
\beta_{a}=v_{a}-\sum_{p \in P_{a}} \sum_{k \geq 2} \frac{1}{k p^{k}}
\end{gathered}
$$

In order to further deepen the analytical methods for studying the Artin hypothesis, it makes sense to obtain approximate estimates of $\beta_{a}, \alpha_{a}$, $v_{a}$ for any values of $a>1$ and establish their asymptotic properties.

The deepening of the theory of the Artin hypothesis is possible with the consideration of another version of the generalization of the Artin hypothesis, one of which is given in [7]. Consider this option from several points of view. First of all, for any $a>1$ and all prime numbers $p \in P$, expression $a^{t} \equiv 1(\bmod p)$ makes sense as an iterative process, i.e. suggest a recursive algorithm for calculating the minimum value of $t>1$, at which this equality is achieved. Let $x_{0}=1$, $x_{n+1} \equiv a x_{n}(\bmod p)$. Iterations will continue until we get:

$$
x_{t} \equiv a x_{t-1}(\bmod p)=1 \text {. }
$$

Such an algorithm can be used for any $p \in P$, and moreover for any natural number $n$ for which $a$ is a primitive root in the generalized sense.

With such an approach to the set of natural numbers $N$ for a given $a>1$, we obtain a discrete dynamical system, which for each value of $p \in P$ has a fixed point. We call such a discrete dynamic system an algebraic dynamical residue system on the base $a$.

Such a dynamic system for each $a>1$ on the basis of Fermat's small theory divides the set of all primes $P$ into a set of classes $\left\{P_{a}(1), P_{a}(2), \ldots, P_{a}(k), \ldots\right\}$. As shown in [8], each class $P_{a}(k)$ is determined by the relation:

$$
P_{a}(x)=\left\{p \mid p \in P \&(p-1) / \operatorname{card}_{0}(p)=k\right\},
$$

where $\operatorname{card}_{a}(p)=t$ is such that $a^{t} \equiv 1(\bmod p)$, i.e. this is the length of the recursion of the corresponding fixed point $p$. In the given paper it is proved that there are infinitely many such classes. It can be assumed that each class $P_{a}(k)$ contains infinitely many primes, and the relation:

$$
\left|P_{a}(k)\right| /|p| \rightarrow 0 \text { при } k \rightarrow \infty
$$

The question of the dynamics of change in $\left|P_{a}(k)\right|$ with increasing $k$ remains open. Obviously, the generalization of the Artin $c(a, i)$ constants satisfies the condition:

$$
\sum_{i=1}^{\infty} c(a, i)=1
$$

It follows from this relation that the constants $c(a, i)$ for each $i$ with a random choice of $p \in P$ 
determine the probability that a given prime number belongs to the set $P_{a}(i)$. From here we follow that the probabilistic approach, the idea of which is developed in the work of Kowalski [6], can be applied to all classes of $P_{a}(i)$ for any $a>1$. If for any $a>1$ that is a primitive root, we put $i=1$, then $P_{a}(i)$ is the set of all primes for which $a$ is their primitive root.

The analysis of classes:

$$
\left\{P_{2}(1), P_{3}(1), P_{6}(1), P_{7}(1), P_{10}(1), \ldots, P_{15}(1)\right\}
$$

and the estimates of the constants $\left\{a(2,1), a(3,1), a(6,1), \ldots, a_{15}(1)\right\} \quad$ obtained in the given paper allow us to state that they are equal to $a(4,1) \cong 0.3798$ on the set of the first ten million prime numbers with an accuracy of four decimal places. This fact allows us to conclude that all the classes listed have the same number of primes, more precisely, the number of primes in sets are of order $n=3798000$, i.e. difference:

$$
\mid\left(\left|P_{a i}(1)\right|-\left|P_{a j}(1)\right| \mid \leq 10000\right. \text {. }
$$

It can be argued that with increasing $n$, the relative value of this difference will tend to zero. An analytical study of classes $P_{a}(1)$ at $n \rightarrow \infty$ will make it possible to establish whether the problem of estimating $c(a, i)$ on the basis of analytical number theory is algorithmically solvable or estimating $\mathrm{Xc}(a, i)$ for any values of $a>1$ and $i \geq 1$ can only be obtained by computer simulation methods. The substantiation of the possibility of this variant is the fact that for $a \in\{4,5,8,9,16\}$ generalized constants $c(a, i)$ on the set of the first ten million prime numbers differ significantly.

The dynamics of class formation in the generalized Artin hypothesis.

Before forming the main provisions of the proposed model for analyzing classes of sets:

$$
P=\left\{\begin{array}{l}
P_{2}(1), P_{3}(1), P_{6}(1), P_{7}(1), P_{10}(1), \\
P_{11}(1), P_{12}(1), P_{13}(1), P_{14}(1), P_{15}(1)
\end{array}\right\}
$$

Constructed on the set of the first ten millions of prime numbers, we draw attention to two facts that will be the subject of further research in this class of dynamical systems, and therefore the associated number theory in the most general sense. First of all, the solution of the structural analysis problem of the reduced system of the set of primes must be represented in such a way that the constructed model can be generalized to the case of all positive integers less than the prime number $p_{10^{7}}$ i.e. ten millionth number, which is equal to $p_{10^{7}}=179424673 \ldots$.. The generalization to the set of all natural numbers is of interest both from the point of view of the study of dynamical systems, and number theory. In addition, the results and methods developed should be presented in a form that would allow them to be transferred to the values of $a>16$. The possibility of such a generalization is necessary because the classes $P_{k^{2}}(i)$ for the values of $k>4$ will have a structure different from the structures of classes $P_{4}(2 m), P_{9}(2 m), P_{16}(2 m)$ at $m \geq 1$ due to the fact that in the cases under consideration the structures of the classes are quite different. If we prove analytically that these differences will remain for all $P_{k^{2}}(i)$ at any $k>4$, then this will serve as a justification for the correctness of the statements:

Statement 1. For any $a>1$ there are many generalized Artin $c(a, i)$ constants such that the equalities hold:

$$
\left\{\begin{array}{l}
\pi(x, a, i)=c(a, i) \cdot \pi(x) \\
\sum_{i=1}^{\infty} c(a, i)=1
\end{array}\right.
$$

Statement 2. The problem of obtaining an asymptotic estimate of $c(a, i)$ for any $a>1, i \geq 1$ is not solvable by analytical methods.

Statement 3 . The problem of estimating $c(a, i)$ is algorithmically solvable by computer simulation methods, but it has subexponential complexity.

In the following, in this paper, attention will be focused on Statement 3. Proof of Claims 1 and 2 will be outlined to a limited extent due to the need to create an analytical method based on analytic number theory, which goes beyond computer modeling methods. In addition, the deepening and development of methods for proving Statement 3 will require developing algorithmic reducibility methods according to the complexity [10] of the developed algorithms to algorithms with a known measure of computational complexity [11]. The need to involve the mathematical theory of algorithmic reducibility is primarily due to the fact that, for any prime number $p \in P$ in the process of computer modeling, it was necessary to systematically prove its simplicity and decompose $p-1$ into simple factors, i.e.:

$$
p-1=\prod_{i=1}^{n} p_{i}^{\alpha_{i}}
$$


To solve these two problems, the developed algorithm was used based on the theory of elliptic curves [12], while parallelizing the number $p-1$, the simplicity of the number $p$ was proved. The algorithm has subexponential complexity, which increases significantly with increasing number $p$. If the value is $p>10^{100}$, then the computational complexity increases to such an extent that the sequential analysis of a large set of prime numbers of large reduced boundaries becomes impossible without using powerful modern computers $[1,2]$.

To solve the problem (6) on the set (5), a software complex was created in the form of the text of computer algebra programs, with which, based on the developed method of experimental mathematics, a systematic analysis of 500,000 consecutive primes was carried out regularly shifted by this value. Thus, many of the first ten million primes were analyzed. For each $a \in P$ (6) a set of classes was built:

$$
P_{a \mid 10^{7}}=\left\{P_{a}(1), P_{a}(2), \ldots, P_{a}(k), \ldots\right\}
$$

which were the object of analysis. When constructing these classes, on each interval, 500,000 consecutive prime numbers were used to construct classes, and the properties of both $p$ primes from these classes and the decomposition of $p-1$ into prime factors were studied. The information about the $P_{a}$ has united in the set of $P_{a \mid 10^{7}}$ i.e. for each $a>1$, classes (7) were built on the set of the first ten million prime numbers that were the object of analysis. Table 1 shows the calculated values of the generalized Artin constants [7, 8].

From table 1, it follows that relation (6) is ideally satisfied. The results will be subject to further analysis.

Regardless of this class of computational algorithms, there will be a systematic need to solve the problem of the dimension of the classification space of a set of numbers, with respect to a certain measure, which in the particular case may be a correlation function between samples of prime numbers from one with a given basis [6].

\section{Structural analysis of classes of generalized Artin's hypothesis}

The systems of classes for $a \in\{4,9,16\}$ satisfy the system of equations (6), but exclude them from further consideration because these numbers are perfect squares and, due to Fermat's small theorem, are not primitive roots of any prime number $p$. Therefore, for each such $a \in\{4,9,16\}$ classes
$P_{a}(2 k+1)$ for $k \in\{0,1,2, \ldots, n, \ldots\}$ there are empty sets. Their systems of classes $\left\{P_{a}(2), P_{a}(4), \ldots, P_{a}(2 k), \ldots\right\}$ describe subgroups of groups of residues $(Z / p Z)$, but they do not contain the generated elements of groups. Although Artin's generalized hypothesis is valid in this case as well, it does not belong to Artin's classical hypothesis. This case requires a separate analysis.

$$
\text { The set } \quad\{2,3,5,6,7,8,10,11,12,13,14,15\}
$$

contains two elements $\{5,8\}$, which require a separate analysis. Although $c(5,1) \cong 0.3936$. is close to the knowledge of $c(2,1) \cong 0.3739$.., nevertheless, this constant differs significantly from the others, by the value of $\Delta \cong 0.012 \ldots$ This difference requires analytical substantiation. But the most important thing for $a=5$ is that all classes:

$$
P_{5}(5), P_{5}(15), P_{5}(25), \ldots, P_{5}(10 k+5), .
$$

empty sets. Analysis of the causes of such a structure requires a separate mathematical consideration. The case of $a=8$ is also an exception in this paper due to the fact that the constants of the set $\left\{c_{8}(1), c_{8}(2), \ldots, c_{8}(k), \ldots\right\}$ evenly satisfy relation (6), but their values differ significantly from the case when $a \in\{2,3,6,7,10,11,12,13,14,15\}$. For the same reasons, case $a=8$. At this stage will not be considered.

From table 1 it follows that in accordance with the results of computer simulation the following equality is true:

$$
\begin{aligned}
& c_{2}(1) \approx c_{3}(1) \approx c_{6}(1) \approx c_{7}(1) \approx c_{10}(1) \approx \ldots \\
& \approx c_{15}(1) \approx 0.3739 . .
\end{aligned}
$$

where $\varepsilon_{i}$ and $\left|\varepsilon_{i}\right| \approx 0,0001$. The value of $\varepsilon_{i}$ at $i \in\{2,3,6,7,10, \ldots, 15\}$ is quite explicable. If you go from the first ten million to the first hundred million and more, then the values of $\varepsilon$ will decrease. We note that fact $c_{13}(13)=0$ was observed, which so far is difficult to explain. In [5] for $a=2$ it is proved that $c_{2}(1) \cong \alpha_{2} \cong A(1)$ can be calculated from the expression:

$$
A(1)=\alpha_{2}=\prod_{p \geq 2}\left(1-\frac{1}{p(p-1)}\right)=0,3739 . .
$$

while $p$ runs through all the sets of primes. No other $c_{3}(1), c_{6}(1), \ldots, c_{15}(1)$ values are given in the 
literature. At least, the analysis by Carella [5], the review by Moree [4] and the dissertation work by Ambrose [3] do not give such data. Note that $c_{a}(1)$ for $a \in P(5)$ in our computational experiment fluctuates, and this is natural due to the fact that the Sets $\left\{P_{2}(1), P_{3}(1), P_{6}(1), P_{7}(1), P_{10}(1), \ldots, P_{15}(1)\right\}$, in addition to the common primes for all pairs of $\left(P_{a_{i}}(1), P_{a_{j}}(1)\right)$, have different prime numbers. Such differences exist for all pairs of $(i, j)$ at $i \neq j$. Even if we assume that in calculating $\alpha_{2}$ and $A(1)$, only primes $p$ were considered, for which $a=2$ is a primitive root, then the differences of Artin's constants $[6,4]$ :

$$
\begin{gathered}
\alpha_{2}=\prod_{p \geq 2}\left(1-\frac{1}{p(p-1)}\right)=0,3739558 \mid 6677689 . . \\
A(1)=\prod_{q \geq 2}\left(1-\frac{1}{q(q-1)}\right)=0,3339558 \mid 136192 . . \\
c_{2}(1)=0,3739 \mid 850 . .[7,8]
\end{gathered}
$$

Not in favor of (8) and (9) due to the following considerations. The estimates (8) and (9) were calculated using the same model, and therefore should not be different. Evaluation (10) begins with the fifth decimal place, i.e. on $\Delta=0.00003$ more and with further clarification cannot be reduced due to the fact that:

Continuation of the Table 5

$$
\left(1-\frac{1}{10^{7}\left(10^{7}-1\right)}\right)=0, \underbrace{99 \ldots 9}_{13} \ldots
$$

Will not change the first six decimal places. At least $\alpha_{2}$ and $A(1)$ should be the same and if they cannot be less than $c_{2}(1)$ by $|\varepsilon|=0,00003$. This fact will lead to the conclusion that analytical evaluations are less accurate for $a=1$ than computer simulation results.

The main result obtained in solving the generalized Artin hypothesis is that equality (6) always holds. All options for solving the Artin problem in a generalized form already at the initial stage, when $a \in\{2,3,5,6,7,8,10,11,12,13,14,15\}$ is divided into several classes $\{2,3,6,7,10,11,12,13,14,15\}, \quad\{5\},\{8\}$. Analytical methods of number theory are unlikely to find a pattern for the formation of sets $P_{a}(1)$ for $a>1$. This may be due to the fact that, as can be seen from table 1 , the set of primes for any $a>1$.

$$
\left\{P_{a}(1), P_{a}(2), \ldots, P_{a}(k), \ldots\right\}
$$

With the growth of the index $k$ classes $P_{a}(i)$ power, therefore, and the composition are significantly different. Following the Gödel theorem [10] and the study of the existence of algorithmically unsolvable problems [11], it can be argued that there is no single algorithm for solving the generalized Artin hypothesis in analytical form. However, the obtained and presented results allow, using computer simulation methods of a set of classes, can be built with any desired accuracy. The computational complexity of the algorithm of such a model belongs to the class $N P$ of complete problems [11].

Since such an algorithm for modeling the formation of classes (11) on the basis of the theory of residues and the small theory of Fermat $[1,2]$ exists for any $a>0$, it follows that both Artin's original hypothesis and its generalizations are correct and there are many factors:

$$
\{c(a, 1), c(a, 2), \ldots, c(a, k), \ldots .\}
$$

It is a probabilistic model of the distribution of primes by classes (11) for any $a>1$. Thus, the validity of Statement 1 can be considered proven. This does not yet imply the validity of Statement 2 . It can be argued that the structures of the resulting classes for $2 \leq a \leq 1$ are not sufficiently stable from the point of view of dynamical systems. Views of the form:

$$
f(a, p): x_{0}=1, x_{m+1} \cong a x_{n}(\bmod p)
$$

for any $a$, an algebraic dynamical system is defined on the set of prime numbers $P$. It can be generalized to the whole set of natural numbers, and even the set of integers. Such a generalization requires a deeper study of the mapping (12) on $N$ or $Z$, or even on finite fields [2] or on elliptic curves [2].

In order to construct an analytical proof of statement 2, let us consider in what respect the set $\left\{P_{2}(1), P_{3}(1), P_{6}(1), P_{7}(1), P_{10}(1), \ldots, P_{15}(1)\right\} \quad$ is $\quad$ in terms of common primes for all pairs of different sets of prime numbers for which the numbers of the set $\{2,3,6,7,10, \ldots, 15\}=A$ are their primitive roots. The need for such an analysis follows from the fact that fact $P_{i}(1) \cap P_{j}(1) \neq 0$ is obvious for any $i \neq j$. This simply follows from the obvious fact:

$$
\sum_{i \in A}\left|P_{i}(1)\right| \cong 3,7 \cdot 10^{7}
$$

While many of the ten million first prime numbers are considered. The results of computer 
ISSN 2221-3805. Електротехнічні та комп’ютерні системи. 2018. № 29 (106)

simulation of dynamic processes of class formation ultimately for a et of ten million first prime in the generalized Artin theory were considered numbers, the data for $P_{i}$ where $i=1,2, \ldots, 32$ :

Table 1

The distribution of prime numbers in 1 to 8 classes in the generalized Artin's conjecture

\begin{tabular}{|c|r|r|r|r|r|r|r|r|}
\hline $\mathrm{c}(\mathrm{a}, \mathrm{i})$ & $\mathrm{P}_{1}$ & \multicolumn{1}{c|}{$\mathrm{P}_{2}$} & \multicolumn{1}{c|}{$\mathrm{P}_{3}$} & $\mathrm{P}_{4}$ & $\mathrm{P}_{5}$ & $\mathrm{P}_{6}$ & $\mathrm{P}_{7}$ & $\mathrm{P}_{8}$ \\
\hline $\mathrm{a}_{2}$ & 0,373985 & 0,280489 & 0,066448 & 0,046711 & 0,018902 & 0,049834 & 0,008912 & 0,035125 \\
\hline $\mathrm{a}_{3}$ & 0,373917 & 0,29922 & 0,066558 & 0,056101 & 0,018952 & 0,03323 & 0,008936 & 0,014018 \\
\hline $\mathrm{a}_{4}$ & 0 & 0,560942 & 0 & 0,093532 & 0 & 0,099675 & 0 & 0,070114 \\
\hline $\mathrm{a}_{5}$ & 0,393683 & 0,265698 & 0,06997 & 0,066438 & 0 & 0,047271 & 0,00941 & 0,016645 \\
\hline $\mathrm{a}_{6}$ & 0,374064 & 0,28049 & 0,066453 & 0,074829 & 0,018905 & 0,049844 & 0,008886 & 0,013984 \\
\hline $\mathrm{a}_{7}$ & 0,374107 & 0,282704 & 0,066437 & 0,068399 & 0,01885 & 0,050256 & 0,008888 & 0,017046 \\
\hline $\mathrm{a}_{8}$ & 0,224342 & 0,168306 & 0,19948 & 0,028059 & 0,011373 & 0,14956 & 0,005354 & 0,021072 \\
\hline $\mathrm{a}_{9}$ & 0 & 0,598315 & 0 & 0,112226 & 0 & 0,066558 & 0 & 0,028052 \\
\hline $\mathrm{a}_{10}$ & 0,374061 & 0,280384 & 0,066512 & 0,071337 & 0,018883 & 0,049893 & 0,008915 & 0,01657 \\
\hline $\mathrm{a}_{11}$ & 0,374062 & 0,281339 & 0,066391 & 0,069482 & 0,018895 & 0,050026 & 0,008889 & 0,017287 \\
\hline $\mathrm{a}_{12}$ & 0,373982 & 0,29914 & 0,066479 & 0,056093 & 0,018903 & 0,033253 & 0,008979 & 0,01404 \\
\hline $\mathrm{a}_{13}$ & 0,376385 & 0,278704 & 0,066969 & 0,069688 & 0,019082 & 0,049535 & 0,009007 & 0,017438 \\
\hline $\mathrm{a}_{14}$ & 0,373924 & 0,280628 & 0,066491 & 0,070678 & 0,018928 & 0,049808 & 0,008922 & 0,017091 \\
\hline $\mathrm{a}_{15}$ & 0,37393 & 0,279563 & 0,06645 & 0,070829 & 0,018896 & 0,050831 & 0,00893 & 0,017697 \\
\hline $\mathrm{a}_{16}$ & 0 & 0,374009 & 0 & 0,186933 & 0 & 0,066445 & & 0,14028 \\
\hline
\end{tabular}

Table 2

The distribution of prime numbers in 9 to 16 classes in the generalized Artin's conjecture

\begin{tabular}{|c|r|r|r|r|r|r|r|r|}
\hline $\mathrm{c}(\mathrm{a}, \mathrm{i})$ & \multicolumn{1}{c}{$\mathrm{P}_{9}$} & $\mathrm{P}_{10}$ & $\mathrm{P}_{11}$ & $\mathrm{P}_{12}$ & $\mathrm{P}_{13}$ & $\mathrm{P}_{14}$ & $\mathrm{P}_{15}$ & $\mathrm{P}_{16}$ \\
\hline $\mathrm{a}_{2}$ & 0,007404 & 0,014146 & 0,003383 & 0,008313 & 0,002388 & 0,00673 & 0,003371 & 0,008798 \\
\hline $\mathrm{a}_{3}$ & 0,00737 & 0,015123 & 0,003406 & 0,024923 & 0,002385 & 0,007112 & 0,003348 & 0,003494 \\
\hline $\mathrm{a}_{4}$ & 0 & 0,028317 & 0 & 0,016608 & 0 & 0,013399 & 0 & 0,017579 \\
\hline $\mathrm{a}_{5}$ & 0,007762 & 0,028423 & 0,0036 & 0,011841 & 0,002513 & 0,006317 & 0 & 0,004117 \\
\hline $\mathrm{a}_{6}$ & 0,007418 & 0,014166 & 0,003406 & 0,008294 & 0,002394 & 0,00668 & 0,003337 & 0,003516 \\
\hline $\mathrm{a}_{7}$ & 0,007413 & 0,014275 & 0,003375 & 0,012179 & 0,002398 & 0,00451 & 0,00336 & 0,004297 \\
\hline $\mathrm{a}_{8}$ & 0,022167 & 0,008466 & 0,002048 & 0,024902 & 0,001426 & 0,004048 & 0,010062 & 0,005277 \\
\hline $\mathrm{a}_{9}$ & 0 & 0,030311 & 0 & 0,049857 & 0 & 0,014278 & 0 & 0,006989 \\
\hline $\mathrm{a}_{10}$ & 0,007392 & 0,014225 & 0,003457 & 0,0127 & 0,00239 & 0,006711 & 0,003352 & 0,004175 \\
\hline $\mathrm{a}_{11}$ & 0,007427 & 0,014238 & 0,003415 & 0,012353 & 0,002362 & 0,006709 & 0,003357 & 0,004329 \\
\hline $\mathrm{a}_{12}$ & 0,007416 & 0,015156 & 0,003413 & 0,024947 & 0,0024 & 0,007124 & 0,003351 & 0,003503 \\
\hline $\mathrm{a}_{13}$ & 0,007444 & 0,01405 & 0,003403 & 0,012382 & 0 & 0,006638 & 0,003359 & 0,004372 \\
\hline $\mathrm{a}_{14}$ & 0,007403 & 0,014135 & 0,003427 & 0,012547 & 0,002377 & 0,006677 & 0,003367 & 0,004257 \\
\hline $\mathrm{a}_{15}$ & 0,007402 & 0,015104 & 0,003379 & 0,011795 & 0,002404 & 0,00666 & 0,003383 & 0,004413 \\
\hline $\mathrm{a}_{16}$ & 0 & 0,018857 & 0 & 0,03323 & 0 & 0,00893 & 0 & 0,035089 \\
\hline
\end{tabular}

Table 3

The distribution of prime numbers in 1 to 16 classes in the generalized Artin's conjecture

\begin{tabular}{|c|c|c|r|r|c|c|c|c|}
\hline $\mathrm{c}(\mathrm{a}, \mathrm{i})$ & $\mathrm{P}_{17}$ & $\mathrm{P}_{18}$ & $\mathrm{P}_{19}$ & $\mathrm{P}_{20}$ & $\mathrm{P}_{21}$ & $\mathrm{P}_{22}$ & $\mathrm{P}_{23}$ & $\mathrm{P}_{24}$ \\
\hline $\mathrm{a}_{2}$ & 0,001386 & 0,005539 & 0,001088 & 0,002369 & 0,001609 & 0,002558 & 0,000744 & 0,006233 \\
\hline $\mathrm{a}_{3}$ & 0,001382 & 0,003659 & 0,00109 & 0,002816 & 0,001577 & 0,002715 & 0,000734 & 0,006239 \\
\hline $\mathrm{a}_{4}$ & 0 & 0,011109 & 0 & 0,00473 & 0 & 0,005103 & 0 & 0,01248 \\
\hline $\mathrm{a}_{5}$ & 0,001442 & 0,005256 & 0,001163 & 0,007071 & 0,001686 & 0,002424 & 0,000783 & 0,002932 \\
\hline
\end{tabular}


Continuation of the Table 3

The distribution of prime numbers in 1 to 16 classes in the generalized Artin's conjecture

\begin{tabular}{|c|r|r|r|r|r|r|r|c|}
\hline $\mathrm{c}(\mathrm{a}, \mathrm{i})$ & $\mathrm{P}_{17}$ & $\mathrm{P}_{18}$ & $\mathrm{P}_{19}$ & $\mathrm{P}_{20}$ & $\mathrm{P}_{21}$ & $\mathrm{P}_{22}$ & $\mathrm{P}_{23}$ & $\mathrm{P}_{24}$ \\
\hline $\mathrm{a}_{6}$ & 0,001395 & 0,005567 & 0,001077 & 0,003799 & 0,001606 & 0,002549 & 0,000745 & 0,006219 \\
\hline $\mathrm{a}_{7}$ & 0,001356 & 0,005578 & 0,001084 & 0,00345 & 0,001565 & 0,002587 & 0,00073 & 0,003035 \\
\hline $\mathrm{a}_{8}$ & 0,000839 & 0,016616 & 0,000657 & 0,001425 & 0,004775 & 0,001541 & 0,000448 & 0,018728 \\
\hline $\mathrm{a}_{9}$ & 0 & 0,00737 & 0 & 0,005649 & 0 & 0,005448 & 0 & 0,012445 \\
\hline $\mathrm{a}_{10}$ & 0,001381 & 0,005537 & 0,001088 & 0,002365 & 0,001588 & 0,002539 & 0,000738 & 0,002924 \\
\hline $\mathrm{a}_{11}$ & 0,001393 & 0,005536 & 0,001118 & 0,003503 & 0,001591 & 0,001693 & 0,000734 & 0,003096 \\
\hline $\mathrm{a}_{12}$ & 0,001356 & 0,003692 & 0,001111 & 0,002825 & 0,001587 & 0,002739 & 0,000738 & 0,006214 \\
\hline $\mathrm{a}_{13}$ & 0,001386 & 0,005461 & 0,001108 & 0,00352 & 0,001571 & 0,002542 & 0,000734 & 0,003078 \\
\hline $\mathrm{a}_{14}$ & 0,001399 & 0,00554 & 0,001094 & 0,003583 & 0,001584 & 0,00254 & 0,000737 & 0,003042 \\
\hline $\mathrm{a}_{15}$ & 0,001388 & 0,005628 & 0,001095 & 0,002823 & 0,001613 & 0,002534 & 0,000736 & 0,002955 \\
\hline $\mathrm{a}_{16}$ & 0 & 0,007399 & 0 & 0,00946 & 0 & 0,003411 & 0 & 0,024912 \\
\hline
\end{tabular}

Table 4

The distribution of prime numbers in 1 to 16 classes in the generalized Artin's conjecture

\begin{tabular}{|c|r|r|r|r|r|r|r|r|}
\hline $\mathrm{c}(\mathrm{a}, \mathrm{i})$ & $\mathrm{P}_{\mathrm{a}, 25}$ & $\mathrm{P}_{\mathrm{a}, 26}$ & $\mathrm{P}_{\mathrm{a}, 27}$ & $\mathrm{P}_{\mathrm{a}, 28}$ & $\mathrm{P}_{\mathrm{a}, 29}$ & $\mathrm{P}_{\mathrm{a}, 30}$ & $\mathrm{P}_{\mathrm{a}, 31}$ & $\mathrm{P}_{\mathrm{a}, 32}$ \\
\hline $\mathrm{a}_{2}$ & 0,000743 & 0,001803 & 0,000821 & 0,0011 & 0,00046 & 0,002513 & 0,000405 & 0,002176 \\
\hline $\mathrm{a}_{3}$ & 0,000736 & 0,00194 & 0,000814 & 0,001349 & 0,000463 & 0,001676 & 0,000407 & 0,000886 \\
\hline $\mathrm{a}_{4}$ & 0 & 0,003598 & 0 & 0,002243 & 0 & 0,005047 & 0 & 0,004397 \\
\hline $\mathrm{a}_{5}$ & 0 & 0,001694 & 0,000883 & 0,001595 & 0,000475 & 0,004998 & 0,000438 & 0,001047 \\
\hline $\mathrm{a}_{6}$ & 0,000754 & 0,001801 & 0,000825 & 0,001802 & 0,000466 & 0,00252 & 0,000403 & 0,000872 \\
\hline $\mathrm{a}_{7}$ & 0,000764 & 0,001823 & 0,000818 & 0,003329 & 0,000462 & 0,002553 & 0,000408 & 0,001074 \\
\hline $\mathrm{a}_{8}$ & 0,000444 & 0,001083 & 0,002464 & 0,000656 & 0,000277 & 0,007577 & 0,000241 & 0,001298 \\
\hline $\mathrm{a}_{9}$ & 0 & 0,003837 & 0 & 0,002665 & 0 & 0,003348 & 0 & 0,001765 \\
\hline $\mathrm{a}_{10}$ & 0,000768 & 0,001814 & 0,000809 & 0,001703 & 0,000457 & 0,002494 & 0,000396 & 0,001034 \\
\hline $\mathrm{a}_{11}$ & 0,000759 & 0,001806 & 0,00081 & 0,00167 & 0,000472 & 0,002544 & 0,0004 & 0,00108 \\
\hline $\mathrm{a}_{12}$ & 0,000736 & 0,001942 & 0,000814 & 0,001329 & 0,000457 & 0,001669 & 0,000401 & 0,000883 \\
\hline $\mathrm{a}_{13}$ & 0,000754 & 0,003586 & 0,000823 & 0,001657 & 0,000467 & 0,002517 & 0,000407 & 0,001092 \\
\hline $\mathrm{a}_{14}$ & 0,000751 & 0,001806 & 0,000833 & 0,001119 & 0,000467 & 0,002521 & 0,00041 & 0,001074 \\
\hline $\mathrm{a}_{15}$ & 0,000759 & 0,001778 & 0,000816 & 0,0017 & 0,000448 & 0,001659 & 0,000411 & 0,001105 \\
\hline $\mathrm{a}_{16}$ & 0 & 0,002401 & 0 & 0,004469 & 0 & 0,003363 & 0 & 0,008779 \\
\hline
\end{tabular}

Tables 1, 2, 3, 4 present estimates of the generalized Artin $c(a, i)$ coefficients for sets $\left\{P_{a}(1), P_{a}(2), \ldots, P_{a}(32)\right\} \quad$ and values of $a \in\{2, \ldots, 32\}$. The relation (6) is satisfied. Consider the set (5). Table 5 and 6 shows the numbers of prime numbers in each of these sets, and in the matrix in Fig. 1 shows the estimates of the values of

$$
\begin{aligned}
& g_{i j} \quad \text { for } \quad i, j \in\{2,3,6, \ldots, 15\} \quad \text { where } \\
& g_{i j}=\left|\left(P_{a_{i}}(1) \cap P_{a_{j}}(1)\right)\right| / 10^{7}, i, j \in\{2,3,6, \ldots, 15\} .
\end{aligned}
$$

To analyze the structure of the common elements of the classes of the set (5), we calculated the power of the intersection of the sets of prime numbers from the same class but with different values of $a$.

Table 5

Calculated the power of the intersection $\mathrm{P}_{2} . . \mathrm{P}_{15}$ and $\mathrm{P}_{2} . . \mathrm{P}_{8}$ of the sets of prime numbers

\begin{tabular}{|c|c|c|c|c|c|c|}
\hline $\mathrm{P}_{\mathrm{a}}(1)$ & $\mathrm{P}_{2}(1)$ & $\mathrm{P}_{3}(1)$ & $\mathrm{P}_{4}(1)$ & $\mathrm{P}_{6}(1)$ & $\mathrm{P}_{7}(1)$ & $\mathrm{P}_{8}(1)$ \\
\hline $\mathrm{P}_{2}(1)$ & 3739850 & 1473465 & 1619069 & 1473724 & 1473189 & 2243420 \\
\hline $\mathrm{P}_{3}(1)$ & 1473465 & 3739165 & 1619473 & 1473840 & 1499886 & 1019963 \\
\hline $\mathrm{P}_{5}(1)$ & 1619069 & 1619473 & 3936827 & 1619982 & 1619637 & 1120427 \\
\hline
\end{tabular}


Continuation of the Table 5

Calculated the power of the intersection $\mathrm{P}_{2} . . \mathrm{P}_{15}$ and $\mathrm{P}_{2} . . \mathrm{P}_{8}$ of the sets of prime numbers

\begin{tabular}{|c|c|c|c|c|c|r|}
\hline $\mathrm{P}_{\mathrm{a}}(1)$ & $\mathrm{P}_{2}(1)$ & $\mathrm{P}_{3}(1)$ & $\mathrm{P}_{4}(1)$ & $\mathrm{P}_{6}(1)$ & $\mathrm{P}_{7}(1)$ & \multicolumn{1}{c|}{$\mathrm{P}_{8}(1)$} \\
\hline $\mathrm{P}_{6}(1)$ & 1473724 & 1473840 & 1619982 & 3740636 & 1474479 & 1020459 \\
\hline $\mathrm{P}_{7}(1)$ & 1473189 & 1499886 & 1619637 & 1474479 & 3741073 & 1019495 \\
\hline $\mathrm{P}_{8}(1)$ & 2243420 & 1019963 & 1120427 & 1020459 & 1019495 & 2243420 \\
\hline $\mathrm{P}_{10}(1)$ & 1328274 & 1473721 & 1619624 & 1474067 & 1474241 & 919445 \\
\hline $\mathrm{P}_{11}(1)$ & 1473861 & 1483252 & 1619653 & 1473915 & 1475645 & 1020038 \\
\hline $\mathrm{P}_{12}(1)$ & 1473422 & 2947001 & 1619356 & 1474110 & 1499938 & 1019723 \\
\hline $\mathrm{P}_{13}(1)$ & 1491904 & 1492608 & 1639496 & 1492105 & 1492599 & 1032542 \\
\hline $\mathrm{P}_{14}(1)$ & 1473908 & 1473525 & 1618994 & 1499154 & 1473955 & 1020374 \\
\hline $\mathrm{P}_{15}(1)$ & 1473266 & 1327012 & 1619169 & 1473986 & 1470552 & 1019609 \\
\hline
\end{tabular}

Calculated the power of the intersection $\mathrm{P}_{2} . . \mathrm{P}_{15}$ and $\mathrm{P}_{10} . . \mathrm{P}_{15}$ of the sets of prime numbers

Table 6

\begin{tabular}{|l|l|l|l|l|l|l|}
\hline $\mathrm{P}_{\mathrm{a}}(1)$ & $\mathrm{P}_{10}(1)$ & $\mathrm{P}_{11}(1)$ & $\mathrm{P}_{12}(1)$ & $\mathrm{P}_{13}(1)$ & $\mathrm{P}_{14}(1)$ & $\mathrm{P}_{15}(1)$ \\
\hline $\mathrm{P}_{2}(1)$ & 1328274 & 1473861 & 1473422 & 1491904 & 1473908 & 1473266 \\
\hline $\mathrm{P}_{3}(1)$ & 1473721 & 1483252 & 2947001 & 1492608 & 1473525 & 1327012 \\
\hline $\mathrm{P}_{5}(1)$ & 1619624 & 1619653 & 1619356 & 1639496 & 1618994 & 1619169 \\
\hline $\mathrm{P}_{6}(1)$ & 1474067 & 1473915 & 1474110 & 1492105 & 1499154 & 1473986 \\
\hline $\mathrm{P}_{7}(1)$ & 1474241 & 1475645 & 1499938 & 1492599 & 1473955 & 1470552 \\
\hline $\mathrm{P}_{8}(1)$ & 919445 & 1020038 & 1019723 & 1032542 & 1020374 & 1019609 \\
\hline $\mathrm{P}_{10}(1)$ & 3740610 & 1473427 & 1474353 & 1492783 & 1473402 & 1474437 \\
\hline $\mathrm{P}_{11}(1)$ & 1473427 & 3740622 & 1483199 & 1492543 & 1472831 & 1472231 \\
\hline $\mathrm{P}_{12}(1)$ & 1474353 & 1483199 & 3739824 & 1491979 & 1473741 & 1327337 \\
\hline $\mathrm{P}_{13}(1)$ & 1492783 & 1492543 & 1491979 & 3763849 & 1492599 & 1491965 \\
\hline $\mathrm{P}_{14}(1)$ & 1473402 & 1472831 & 1473741 & 1492599 & 3739237 & 1472951 \\
\hline $\mathrm{P}_{15}(1)$ & 1474437 & 1472231 & 1327337 & 1491965 & 1472951 & 3739304 \\
\hline
\end{tabular}

Analysis of the structure of this matrix allows us to conclude about the structure of the set $P_{a_{i}}(1) \cap P_{a_{j}}(1)$. From equality:

$$
\left|\left(P_{a_{i}}(1) \cap P_{a_{j}}(1)\right)\right|=\left|\left(P_{a_{e}}(1) \cap P_{a_{k}}(1)\right)\right|
$$

$$
\begin{aligned}
& \text { It } \quad \text { does not } \quad \text { follow } \begin{array}{r}
\text { that } \\
P_{a_{i}}(1) \cap P_{a_{j}}(1)=P_{a_{e}}(1) \cap P_{a_{k}}(1)
\end{array} \\
& a_{i} \neq a_{j} \neq a_{e} \neq a_{k} .
\end{aligned}
$$

Table 5 and 6 shows the total number of prime numbers for all pairs of classes identified. Analysis of the table allows us to conclude that at the level of primitive roots, almost all pairs of classes have stable in power subsets of common primes of almost the same power. This indicates the existence of a general pattern of formation of these classes. However, attention should be paid to classes $P_{3}(1)$ and $P_{12}(1)$ in which the proportion of common primes is close to 0.8 . This fact confirms the assumption that the possibility of an analytical description of sets $P_{a}(1)$ for an arbitrary primitive root $a>1$ is improbable. It is necessary to improve both computer simulation methods and the development of an analytical theory of the formation of classes of primes in classes $P_{a}(1)$ as functions $a$. The study of classes $P_{a}(k)$ for arbitrary numbers $a>1$ and $k \in N$ is a separate problem, the solution of which is important both from the point of view of studying algebraic systems and from the point of view of studying systems of primitive roots of proper subgroups of group $(Z / p Z)^{*}$ for any $p \in P$. This problem can be generalized to the case of $(Z / n Z)^{*}$ where $n>1$ is an arbitrary natural number.

A key question arises: What properties of natural numbers from the set $\{2,3,6,7,11,12,13,14,15\}$ cause the established fact: $c(2,1) \cong c(3,1) \cong c(6,1) \cong . . \cong c(15,1) \cong 0.37379 .$. 
on the set of the first ten million prime numbers. It is not clear which $a>16 \& a \neq k^{2}$ applies to this property. Need to explain why $a(5,5)=a(5,15)=a(5,25)=. .=0$ ? What properties of the number $a=8$ cause a different structure?

\section{Conclusions}

Thus, the hypothesis of Artin in both the original and the generalized form was solved by computer simulation methods. It is established that for different $a>1$ the structure of Artin sets dynamically changes depending on the value of $a$. It is proved that property $a>1$ (6) holds. Further research directions in the field of algebraic dynamical systems and related generalizations of Artin's conjecture to the set of natural numbers are determined.

\section{References}

1. Manin, Y. and Panchishkin, A. (2009), "Introduction to the modern theory of numbers", Moscow, MTSNMO, p. 551.

2. Crandall, R. and Pomerance, C. (2005), "Prime Numbers A Computational Perspective", Portland, Springer, p. 664.

3. Ambrose, D. (2014), “On Artin's Primitive Root Conjecture", Dissertation zur Erlangung des mathematisch-naturwissenschaftlichen Doktorgrades "Doctor rerum naturalium" der
Georg-August-Universit at Gottingen der Georg-August-Universitat Gottingen.

4. Moree, P. (2012), "Artin's Primitive root conjecture a survey", Integres, 12, arxiv: math/0412262v2 p. 87.

5. Carella, N. (2018), "The Generalized Artin Primitive Root Conjecture, (European journal of pure and applied math. Vol. 11, No. 1", p. 23-34.

6. Kowalski, E. (2018), "Arithmetic Randonnee. An Introduction to probabilistic number theory" draft Version, p. 120.

7. Vostrov, G. and Opiata, R. (2018) "ELIT 2018 $X$ th International Scientific and Practical Conference Electronics and Information Technologies" Proceedings, "Mathematical modeling of nonlinear dynamic processes in information technologies of mathematics", p. 1-3.

8. Vostrov, G. and Opiata, R. (2018), "Electrotechnical and computer systems. №29", "Generalized Artina hypothesis and computer information model its solutions", are publishing.

9. Kowalski, E. (2018), "Analitic Problems for Elliptic Curves", p. 1-65.

10. Takeuti, G. (1975), "Proof theory", North Holland publishing company, p. 412.

11. Rogers, H. (1972), "Theory of recursive functions and effective computability", $\mathrm{M}$.: Mir, p. 586.

\title{
АНАЛІЗ СТРУКТУР АЛГЕБРАЇЧНИХ ДИНАМІЧНИХ СИСТЕМ НА ОСНОВІ КОМПЬЮТЕРНОГО РІШЕННЯ УЗАГАЛЬНЕНОЇ ГІПОТЕЗИ АРТИНОВ
}

\author{
Г. М. Востров , Р. Ю. Опята \\ Одеський національний політехнічний університет
}

\begin{abstract}
Анотація. В роботі розглянута узагальнена гіпотеза Артіна. Наведено аналіз алгебрайчних динамічних систем на безлічі простих чисел. Вивчено властивості динамічних систем алгебри. На основі комп'ютерного моделювання побудовано рімення узагальненої гіпотези Артіна. Побудована класифікація простих чисел для будь-якого натурального числа $a \geq 1$. Досліджено властивості класів простих чисел. Розроблено метод структурного аналізу алгебраїчних динамічних систем 3 близькими значеннями узагальнених констант Артіна. Встановлено що для будь-якого $a \geq 1$ кожен клас має вірогідну міру, і сума заходів класів прагне до одиниці.

У теперішній час відомо велика кількість математичних проблем, щодо яких, відсутня яка-небудь інформація щуодо їх розв'язання. В області сучасної теорії чисел великий перелік таких проблем з детальним аналізом наведено в монографіях і ряді інших статей. Однією з таких проблем є гіпотеза Артіна сформована в 1927 рочі. Важливою проблемою теорії чисел є опис закону розподілу простих чисел. Дане завдання було вирішене Адамаром і Валле-Пусеном, незалежно один від одного, в 1896 poui.

Можна стверджувати, що майже сто років гіпотеза Артіна є об'єктом дослідження груп математиків, дослідницьких математичних центрів, університетів а також $i$ окремих математиків. В останні роки з'явилися фундаментальні огляди всіх наукових публікацій в тій чи іншій мірі спрямованих на узагальнення і приватне рімення даної проблеми. Слід виділити оглядову статтю Могее з досить глибоким аналізом різних методів вирімення проблеми Артіна. В огляді
\end{abstract}


автора для випадку призводить оцінку яка є константа Артіна тобто . Дана оцінка константи Артіна для отримана на основі виразу A(1), де безліч всіх простих чисел. В роботі Могее не наводиться аналітичні доказ изього співвідношення.

Узагальнена гіпотеза Артіна. Алгебраїчна динамічна система. Комп'ютерне рішення узагальненої гіпотези Артіна. Класифікачія простих чисел за основою а.

Ключові слова: Узагальнена гіпотеза Артіна. Алгебраӥчна динамічна система. Комп'ютерне рішення узагальненої гіпотези Артіна. Класифікація простих чисел за основою $а$.

\title{
АНАЛИЗ СТРУКТУР АЛГЕБРАИЧЕСКИХ ДИНАМИЧЕСКИХ СИСТЕМ НА ОСНОВЕ КОМПЬЮТЕРНОГО РЕШЕНИЯ ОБОБЩЕННОЙ ГИПОТЕЗЫ АРТИНА
}

\author{
Г. Н. Востров, Р. Ю. Опята \\ Одесский национальный политехнический университет
}

\begin{abstract}
Аннотация. В работе рассмотрена обобщенная гипотеза Артина. Приведен анализ алгебраических динамических систем на множестве простых чисел. На основе компьютерного моделирования построено решение обобщенной гипотезы Артина. Построена классификация простых чисел для любого натурального числа $a \geq 1$. Разработан метод структурного анализа алгебраических динамических систем с близкими значениями обобщенных констант Артина.

Ключевые слова: Обобщенная гипотеза Артина. Алгебраическая динамическая система. Компьютерное решение обобщенной гипотезы Артина. Классификация простых чисел по основанию $а$.
\end{abstract}

Received 20.03.2019

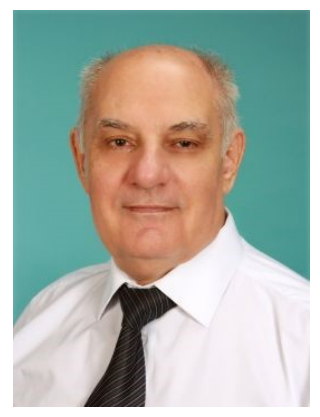

George Vostrov, Ph. D. of Technical Sciences, Associate Professor of the Department of Applied Mathematics and Information Technologies, Odessa National Polytechnic University. Shevchenko ave., 1, Odessa, Ukraine.

E-mail: vostrov@gmail.com, mob.+380503168776

Востров Георгій Миколайович, кандидат технічних наук, доцент кафедри прикладної математики та інформаційних технологій Одеського національного політехнічного університету. Просп. Шевченко, 1, Одеса, Україна.

Эл. адрес: vostrov@gmail.com, тел. +380503168776

ORCID ID: 0000-0003-3856-5392

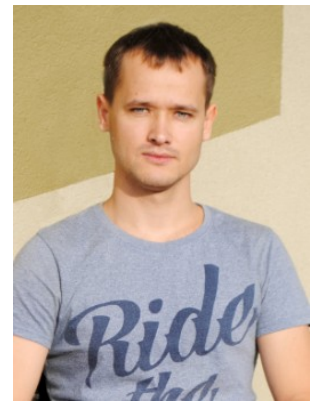

Roman Opiata, $\mathrm{PhD}$ student of the Department of Applied Mathematics and Information Technologies, Odessa National Polytechnic University. Shevchenko ave., 1, Odessa, Ukraine.

E-mail: roma.opyata@gmail.com, mob.+38095249753

Опята Роман Юрійович, аспірант кафедри прикладної математики та інформаційних технологій Одеського національного політехнічного університету. Просп. Шевченко, 1, Одеса, Україна.

Эл. адрес: roma.opyata@gmail.com, тел. +38095249753

ORCID ID: 0000-0001-5806-9615 